\title{
Pengaruh Kompetensi Pedagogik Guru Terhadap Motivasi dan Prestasi Belajar Matematika Siswa
}

\author{
Nurhafizah $^{1 *}$, Sripatmi ${ }^{2}$, Sri Subarinah ${ }^{2}$, Laila Hayati2 \\ ${ }^{1}$ Mahasiswa Pendidikan Matematika, Universitas Mataram, Mataram, Indonesia \\ 2 Pendidikan Matematika, Universitas Mataram, Mataram, Indonesia \\ *Corresponding Author e-mail: oyonnurhafizah@gmail.com
}

Received: 26-01-2021; Revised: 24-03-2021; Published: 25-03-2021

\begin{abstract}
This study aims to determine: 1) whether there is an effect of teacher pedagogical competence on mathematics learning motivation of Mataram City Junior High School students, 2) whether there is an effect of teacher pedagogic competence on mathematics learning achievement of Mataram City Junior High School students, and 3) whether there is a relationship between motivation and mathematics learning achievement of Mataram City Junior High School students. This type of research is ex post facto with a quantitative approach. The population in this study were all mathematics subject teachers and students of Mataram City Junior High School. The selected samples were 6 teachers and 164 students. The sampling technique is stratified, namely cluster sampling and random cluster sampling. Data collection techniques used documents, questionnaires and tests. The conclusions obtained are 1) there is a significant influence between teacher pedagogical competence on mathematics learning motivation of Mataram City Junior High School students, 2) there is no influence between teacher pedagogic competence on mathematics learning achievement of Mataram City Junior High School students, and 3) there is no relationship between motivation and mathematics learning achievement of Mataram City Junior High School students.
\end{abstract}

Keywords: pedagogical competence; mathematics learning motivation; mathematics learning achievement

\begin{abstract}
Abstrak
Penelitian ini bertujuan untuk mengetahui: 1) ada tidaknya pengaruh dari kompetensi pedagogik guru terhadap motivasi belajar matematika siswa SMPN kota Mataram, 2) ada tidaknya pengaruh dari kompetensi pedagogik guru terhadap prestasi belajar matematika siswa SMPN kota Mataram, dan 3) hubungan antara motivasi dan prestasi belajar matematika siswa SMPN kota Mataram. Jenis penelitian ini adalah ex post facto dengan pendekatan kuantitatif. Populasi dalam penelitian ini adalah seluruh guru mata pelajaran matematika dan siswa SMPN kota Mataram. Sampel yang terpilih sebanyak 6 guru dan 164 siswa. Teknik pengambilan sampel secara bertingkat yaitu cluster sampling dan random claster sampling. Teknik pengumpulan data menggunakan dokumen, angket dan tes. Kesimpulan yang diperoleh adalah 1) ada pengaruh signifikan antara kompetensi pedagogik guru terhadap motivasi belajar matematika siswa SMPN kota Mataram, 2) tidak ada pengaruh antara kompetensi pedagogik guru terhadap prestasi belajar matematika siswa SMPN kota Mataram, serta 3) tidak ada hubungan antara motivasi dan prestasi belajar matematika siswa SMPN kota Mataram.
\end{abstract}

Kata Kunci: kompetensi pedagogik; motivasi belajar matematika; prestasi belajar matematika

\section{Cara Mengutip}

Nurhafizah., Sripatmi., Subarinah, S., \& Hayati, L. (2021). Pengaruh kompetensi pedagogik guru terhadap motivasi dan prestasi belajar matematika siswa. Griya Journal of Mathematics Education and Application, 1(1), 1-10. 


\section{PENDAHULUAN}

Pendidikan berperan penting dalam perkembangan ilmu pengetahuan dan teknologi. Oleh sebab berkembangnya ilmu pendidikan dan teknologi menuntut sumber daya manusia (SDM) yang berkualitas. Salah satu komponen penting yang harus mendapatkan perhatian serius adalah guru. Peran sentral guru dalam meningkatkan kualitas pendidikan sangat urgent untuk dilakukan. Hampir semua usaha reformasi dibidang pendidikan seperti penerapan kurikulum dan penerapan metode pengajaran baru pada akhirnya tergantung kepada guru. Tanpa mereka usaha untuk mendorong siswa dalam mencapai prestasi yang tinggi dengan segala upaya meningkatkan kualitas pendidikan tidak akan mencapai maksimal (Wahyudi \& Kurniati, 2012). Disisi lain terdapat beberapa permasalahan yang dihadapi guru antara lain 1) kesulitan dalam menghadapi adanya perbedaan individu siswa yang disebabkan oleh IQ, watak atau latar belakang kehidupan siswa, 2) kesulitan dalam menentukan materi yang cocok dengan siswa yang dihadapinya, 3) kesulitan dalam memilih metode yang tepat, dan 4) kesulitan dalam mengadakan evaluasi karena kadang-kadang kelebihan waktu atau kekurangan waktu (Zuhairini dkk., 1993).

Pernyataan tersebut ternyata sejalan dengan fakta yang terjadi di lapangan bahwa pencapaian prestasi pendidikan di Nusa Tenggara Barat (NTB) masih rendah. Berdasarkan pemaparan oleh Kepala Dikbud, H. Rusman menyatakan bahwa "Kualitas pendidikan di NTB masih berada di posisi rendah. NTB ranking 33 dari 34 provinsi di indonesia" (ZWR, 2019). Rendahnya pencapaian prestasi khususnya pada mata pelajaran matematika siswa pada tahun 2003, hasil tes dari Trend In International Mathematics and Science Study (TIMSS) terlihat pada hasil tes tersebut menempatkan siswa indonesia di peringkat 34 penguasaan matematika dari 48 negara yang disurvai. Lebih spesifik, berdasarkan data dari Kemendikbud diketahui bahwa nilai rata-rata ujian nasional ditingkat SMP/MTs di NTB. Pada 3 tahun terakhir, mata pelajaran matematika padai tahun 2017 -2019 memperoleh nilai 46,02; 36,32, dan 38,76 dimana nilai rata-rata UN pada tiga terakhir tersebut berada dibawah nilai rata-rata secara nasional.

Lebih lanjut berdasarkan observasi yang dilakukan oleh peneliti pada 16 April 2019 di SMPN 22 Mataram, 20 April 2019 di SMPN 8 Mataram, dan 29 April 2019 di SMPN 7 Mataram diperoleh hasil bahwa motivasi belajar matematika siswa rata-rata rendah. Hal ini dapat dlihat dari aktivitas siswa selama pembelajaran berlangsung di kelas. Umumnya para siswa hanya hanya duduk diam dan mendengarkan penjelasan guru tanpa adanya tanggapan misalnya siswa kurang aktif bertanya, jarang mencatat hal-hal yang disampaikan, ada diantara siswa yang membuat keributan ketika pembelajaran berlangsung misalnya berbicara sendiri dengan teman yang lain. Masih banyaknya siswa untuk belajar harus diperintah tanpa ada kesadaran dari diri sendiri secara mandiri, beberapa siswa tidak mengerjakan tugas rumah atau tugas itu dikerjakan di sekolah ketika akan dikumpulkan dan kurang memiliki inisiatif dalam mengembangkan kemampuan berfikir yang dimilikinya. 
Hasil wawancara dengan beberapa guru mata pelajaran matematika diperoleh informasi bahwa guru masih sering menggunakan model pembelajaran langsung yaitu pembelajaran berpusat pada guru dimana terjadi pembelajaran hanya satu arah dari guru yang mentransformasikan pengetahuan kepada siswa yang menyebabkan kurangnya interaksi atau timbal balik antara guru dan siswa dalam proses pembelajaran sehingga membuat kegiatan pembelajaran menjadi monoton dan membosankan selain itu juga masih ada guru yang hanya menyiapkan perangkat pembelajaran untuk kepentingan administrasi dan supervisi saja namun tidak melaksanakan pembelajaran sesuai dengan RPP yang telah di buat ketika mengajar dikelas sehingga terjadi proses pembelajaran yang tidak efektif dan efisien misalkan guru sering kekurangan waktu ketika melakukan evaluasi pembelajaran.

Berdasarkan kajian teori adapun faktor-faktor yang mempengaruhi motivasi belajar antara lain: 1) cita-cita atau aspirasi siswa yaitu cita-cita akan memperkuat motivasi belajar baik instrinsik maupun ekstrinsik, sebab tercapainya suatu cita-cita akan mewujudkan aktualisasi diri, 2) kemampuan siswa yaitu keinginan seorang perlu dibarengi dengan kemampuan dan kecakapan dalam pencapaiannya, 3) kondisi siswa yaitu kondisi siswa yang meliputi kondisi jasmani dan rohani mempengaruhi motivasi belajar. Seseorang siswa yang sedang sakit, lapar, atau marah-marah tentunya akan mengganggu perhatian belajar, sehingga secara otomatis motivasi belajar seorang siswa tersebut tidak ada, dan 4) kondisi lingkungan siswa yaitu lingkungan siswa dapat berupa keadaan alam, lingkungan tempat tinggal, pergaulan sebaya dan kehidupan kemasyarakatan (Emda, 2017). Sedangkan adapun aktor-faktor yang mempengaruhi prestasi belajar dalam digolongkan ke dalam dua golongan yaitu faktor intern yang bersumber pada diri siswa dan faktor ekstern yang bersumber dari luar diri siswa. Faktor intern terdiri dari kecerdasan atau intelegensi, perhatian, bakat, minat dan motivasi, kematangan, kesiapan dan kelelahan. Sedangkan faktor ekstern terdiri dari lingkungan keluarga, lingkungan sekolah dan lingkungan masyarakat (Slameto, 2010). Berdasarkan pernyataan-pernyataan tersebut, peneliti tertarik melakukan penelitian dengan judul "Pengaruh Kompetensi Pedagogik Guru Terhadap Motivasi dan Prestasi Belajar Matematika Siswa”.

\section{METODE}

Jenis penelitian yang digunakan adalah penelitian Ex Post Facto. Penelitian ini dilakukan di beberapa sekolah SMPN di kota Mataram yaitu SMPN 7 Mataram, SMPN 8 Mataram, SMPN 10 Mataram, SMPN 17 Mataram, SMPN 14 Mataram dan SMPN 22 Mataram. Penelitian ini dilaksanakan pada semester ganjil tahun ajaran 2019/2020. Dalam penelitian ini dilakukan teknik pengambilan sampel secara bertingkat yaitu Cluster sampling dan Cluster random sampling. Cluster sampling dilakukan untuk pengambilan sekolah sampel dan kelas sampel, selanjutnya, Cluster random sampling untuk pengambilan guru sampel lebih lanjut untuk menentukan strata mengelompokkan guru dalam kemampuan tinggi, cukup dan rendah. Untuk lebih jelas teknik pengambilan sampel yang dilakukan dalam penelitian ini dapat dilihat pada Tabel 1 berikut ini. 
Tabel 1. Pengambilan Sampel dalam Penelitian

\begin{tabular}{ccccc}
\hline Sekolah & Nama guru & Kriteria pedagogik & Kelas & Banyak siswa \\
\hline SMPN 10 Mataram & Guru D & Tinggi & VII E & 28 \\
SMPN 17 Mataram & Guru N & Tinggi & VIII D & 30 \\
SMPN 22 Mataram & Guru S & Cukup & VII A & 20 \\
SMPN 8 Mataram & Guru Y & Cukup & VII G & 27 \\
SMPN 14 Mataram & Guru A & Rendah & VIII B & 27 \\
SMPN 7 Mataram & Guru O & Rendah & VIII F & 32 \\
\hline
\end{tabular}

Teknik pengumpulan data yang digunakan dalam penelitian ini adalah menggunakan angket, soal, wawancara, dokumentasi dan observasi. Dalam penelitian ini angket yang diberikan adalah angket motivasi belajar matematika. Selanjutnya, soal yang diberikan adalah soal tes prestasi belajar matematika. Kemudian wawancara yang dilakukan peneliti kepada beberapa guru matematika SMPN kota mataram tahun ajaran 2019/2020 bertujuan untuk memperoleh informasi terkait kompetensi pedagogik guru. sedangkan dokumentasi dilakukan untuk mendapatkan data Uji Kompetensi Guru matematika SMPN kota mataram pada tahun 2015 khususnya data uji kompetensi pedagogikguru yang diperoleh dari LPMP kota mataram. Adapun observasi dilakukan untuk mengetahui tingkat motivasi belajar matematika siswa di beberapa sekolah di SMPN kota mataram tahun ajaran 2019/2020.

Penelitian ini menggunakan instrumen angket motivasi belajar matematika dan soal tes prestasi belajar matematika siswa. Angket motivasi belajar matematika terdiri atas 23 pernyataan. Sedangkan soal tes prestasi belajar matematika siswa berupa soal uraian yang terdiri atas soal untuk kelas VII pada materi bilangan dan soal untuk kelas VIII pada materi pola bilangan. Instrumen angket dan soal terlebih dahulu dilakukan uji validitas. Uji validitas yang digunakan adalah validitas isi dan empiris. Instrumen penelitian divalidasi oleh salah satu dosen pendidikan matematika FKIP Universitas Mataram dengan hasil validitas bahwa instrumen yang digunakan telah valid atau layak digunakan.

Sementara hasil uji empiris yang dilakukan di SMPN 1 mataram hasil Uji validitas empiris angket motivasi belajar matematika yang diterapkan kepada 31 responden kelas VIII-J. Berdasarkan hasil uji coba dan uji validitas didapatkan 23 pernyataan valid dari 36 pernyataan yang diujicobakan. Adapun hasil Uji validitas empiris tes prestasi belajar matematika yang diterapkan kepada 27 responden kelas VII K dengan 13 butir soal uraian. Sementara itu tes prestasi belajar kelas VIII diterapkan kepada 32 responden kelas VIII J dengan 13 butir soal uraian. Berdasarkan hasil uji coba dan uji validitas adapun untuk soal kelas VII didapatkan 11 butir soal valid dari 13 butir soal yang diujicobakan. Sementara itu untuk soal kelas VIII didapatkan 10 butir soal valid dari 13 butir soal yang diujicobakan.

Adapun teknik analisis data yang digunakan dalam penelitian ini menggunakan statistik deskriptif dan inferensial. Sebelum melakukan analisis data, terlebih dahulu dilakukan pengkategorian motivasi dan prestasi belajar matematika siswa. Adapun untuk 
mengetahui gambaran umum tingkat kecenderungan motivasi dan prestasi belajar matematika siswa dapat dianalisis dengan menggunakan $\mathrm{Mi}$ (Mean ideal) dan SDi (standar deviasi ideal).

\section{HASIL DAN PEMBAHASAN}

\subsection{Hasil Penelitian}

\subsubsection{Uji prasyarat analisis terhadap data penelitian}

\subsubsection{Uji normalitas}

Pada penelitian ini pengujian normalitas dilakukan dengan menggunakan Uji Kolomogrov Smirnov dengan bantuan aplikasi SPSS 21.

a. Uji normalitas data motivasi belajar matematika

Hasil uji normalitas data motivasi belajar matematika dalam penelitian ini dapat dilihat pada Tabel 2 berikut ini.

Tabel 2. Hasil Uji Kolmogorov Smirnov Motivasi Belajar Matematika

\begin{tabular}{llr}
\hline \multicolumn{3}{c}{ Motivasi Belajar Matematika } \\
\hline $\mathrm{N}$ & \multicolumn{1}{c}{ Mean } &, 0000000 \\
\cline { 2 - 3 } Normal Parameters & Std. & 8,93095952 \\
& Deviation &, 055 \\
\hline \multirow{2}{*}{ Most Extreme } & Absolute &, 054 \\
\cline { 2 - 3 } Differences & Positive &,- 055 \\
\cline { 2 - 3 } & Negative &, 707 \\
\hline Kolmogorov-Smirnov Z & &, 699 \\
\hline Asymp. Sig. (2-tailed) & & \\
\hline
\end{tabular}

Berdasarkan Tabel 2 didapatkan bahwa nilai D maks data motivasi belajar matematika sebesar 0.055 kurang dari nilai tabel Kolomogriv-Smirnov sebesar 0,106 maka $H_{0}$ diterima dapat disimpulkan bahwa data motivasi belajar matematika berdistribusi normal.

b. Uji normalitas data prestasi belajar matematika

Hasil uji normalitas data prestasi belajar matematika dalam penelitian ini dapat dilihat pada Tabel 3 berikut ini.

Tabel 3. Hasil Uji Kolmogorov Smirnov Prestasi Belajar Matematika

\begin{tabular}{llr}
\hline \multicolumn{3}{c}{ One-Sample Kolmogorov-Smirnov Test } \\
\hline $\mathrm{N}$ & \multicolumn{1}{c}{ Mean } & 164 \\
\cline { 2 - 3 } Normal Parameters ${ }^{\mathrm{a} b \mathrm{~b}}$ & Std. &, 0000000 \\
& Deviation & 1,78433503 \\
& Absolute &, 138 \\
\cline { 2 - 3 } Most Extreme & Positive &, 134 \\
\cline { 2 - 3 } & Negative &,- 138 \\
\hline Kolmogorov-Smirnov Z & & 1,765 \\
\hline Asymp. Sig. (2-tailed) & &, 004 \\
\hline
\end{tabular}


Berdasarkan Tabel 3 didapatkan bahwa nilai D maks data prestasi belajar matematika sebesar 0.138 lebih dari nilai tabel kolomogriv-Smirnov sebesar 0,106 maka $H_{0}$ ditolak dapat disimpulkan bahwa data motivasi belajar matematika tidak berdistribusi normal.

\subsubsection{Uji homogenitas}

Pada penelitian ini pengujian normalitas dilakukan dengan menggunakan Uji Bartlett.

a. Uji homogenitas data motivasi belajar matematika

Berdasarkan hasil perhitungan uji homogenitas data motivasi belajar matematika

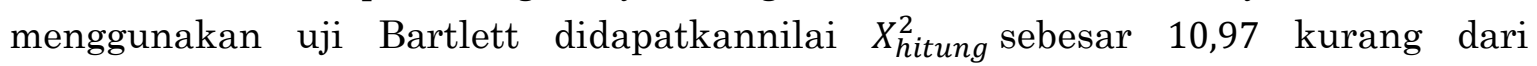
nilai $X_{\text {tabel }}^{2}$ sebesar 11,07 sehingga diperoleh kesimpulan bahwa $H_{0}$ diterima. Jadi dapat disimpulkan bahwa data motivasi belajar matematika homogen.

b. Uji homogenitas data prestasi belajar matematika

Berdasarkan hasil perhitungan uji homogenitas data prestasi belajar matematika menggunakan uji Bartlett didapatkan nilai $X_{\text {hitung }}^{2}$ sebesar 55,46 lebih dari nilai $X_{\text {tabel }}^{2}$ sebesar 11,07 sehingga diperoleh kesimpulan bahwa $H_{a}$ diterima. Jadi dapat disimpulkan bahwa data prestasi belajar matematika tidak homogen.

\subsubsection{Uji hipotesis}

Setelah melakukan uji normalitas dan uji homogenitas sebagai uji prasyarat, selanjutnya dilakukan uji hipotesis sebagai berikut

a. Uji one way anova (Uji F)

Berdasarkan hasil perhitungan uji $\mathrm{F}$ dari perbedaan skor motivasi belajar matematika ditinjau dari kategori kompetensi pedagogik guru didapatkan nilai $\mathrm{F}_{\text {hitung. sebesar 3,67 }}$ lebihdarinilai $\mathrm{F}_{\text {tabel }}$ sebesar 3,04 $\mathrm{makaH}_{a}$ diterima. Jadi dapat disimpulkan bahwa terdapat pengaruh kompetensi pedagogik guru terhadap motivasi belajar matematika siswa SMPN kota Mataram tahun ajaran 2019/2020.

b. Uji Krukall Wallis

Berdasarkan hasil perhitungan uji Kruskall Wallis dari perbedaan nilaiprestasi belajar matematika ditinjau dari kategori kompetensi pedagogik guru didapatkan nilai Hhitung. sebesar 5,5999 kurang dari nilai chi kuadrat tabel sebesar 5,9991, maka $H_{0}$ diterima. Jadi dapat disimpulkan bahwa tidak terdapat pengaruh kompetensi pedagogik guru terhadap prestasi belajar matematika siswa SMPN kota Mataram tahun ajaran 2019/2020.

c. Uji Kendal Tau

Berdasarkan hasil perhitungan uji Kendal Tau diperoleh bahwa harga Z hitung pada korelasi Kendall Tau sebesar 1,539, sedangkan Z tabel sebesar 1,96 (lampiran 32). Karena Z hitung $<$ Z tabel, berarti bahwa tidak terdapat hubungan antara motivasi dan prestasi belajar matematika siswa SMPN di kota Mataram tahun ajaran $2019 / 2020$. 


\subsection{Pembahasan}

Berdasarkan hasil penelitian yang telah dilakukan di beberapa sekolah SMPN di kota Mataram tahun ajaran 2019/2020 diperoleh frekuensi variabel motivasi dan prestasi ditinjau dari kategori kompetensi pedagogik guru dapat dilihat pada Tabel 5 berikut ini.

Tabel 4. Rekapitulasi kategori motivasi dan prestasi belajar matematika ditinjau dari kategori kompetensi pedagogik guru

\begin{tabular}{clcl}
\hline \multirow{2}{*}{ Pedagogik terikat } & \multirow{2}{*}{ Kategori } & \multicolumn{2}{c}{ Frekuensi } \\
\cline { 3 - 4 } & & Motivasi & Prestasi \\
\hline \multirow{3}{*}{ Tinggi } & 1. Sangat tinggi & 14 & 0 \\
& 2. Tinggi & 25 & 0 \\
& 3. Sedang & 18 & 0 \\
& 4. Rendah & 1 & 14 \\
& 5. Sangat rendah & 0 & 44 \\
\hline \multirow{5}{*}{ Cukup } & 1. Sangat tinggi & 8 & 2 \\
& 2. Tinggi & 23 & 2 \\
& 3. Sedang & 15 & 10 \\
& 4. Rendah & 1 & 6 \\
& 5. Sangat rendah & 0 & 27 \\
\hline \multirow{5}{*}{ Rendah } & 1. Sangat tinggi & 6 & 0 \\
& 2. Tinggi & 26 & 1 \\
& 3. Sedang & 18 & 4 \\
& 4. Rendah & 9 & 6 \\
& 5. Sangat rendah & 0 & 48 \\
\hline
\end{tabular}

Berdasarkan Tabel 4 terlihat bahwa siswa berkategori motivasi belajar sangat tinggi memiliki frekuensi terbanyak pada kategori kompetensi pedagogik guru tinggi yaitu 14 siswa, disusul kompetensi pedagogik cukup kemudian kompetensi pedagogik rendah. Kemudian jumlah siswa berkategori tinggi dan sedang untuk setiap kategori kompetensi pedagogik guru baik tinggi, cukup dan rendah adalah seimbang. Selanjutnya, siswa berkategori motivasi belajar rendah memiliki frekeunsi terbanyak pada kategori kompetensi pedagogik guru rendah juga yaitu 9 siswa, kemudian kompetensi pedagogik tinggi dan cukup yang memiliki frekuensi siswa yang sama. Sementara itu, siswa berkategori motivasi belajar sangat rendah untuk setiap kategori kompetensi pedagogik guru baik tinggi, cukup dan rendah tidak ada.

Sedangkan untuk siswa berkategori prestasi belajar sangat tinggi hanya terdapat pada kategori kompetensi pedagogik cukup yaitu sebanyak 2 siswa. Begitu juga siswa berkategori prestasi sedang memiliki frekuensi terbanyak pada kategori kompetensi pedagogik guru cukup yaitu 10 siswa, disusul kompetensi pedagogik rendah. Selanjutnya, siswa berkategori prestasi belajar rendah memiliki frekuensi terbanyak pada kategori kompetensi pedagogik guru tinggi yaitu 9 siswa. Kemudian kompetensi pedagogik cukup dan rendah yang memiliki frekuensi siswa yang sama. Sementara itu, siswa berkategori prestasi belajar sangat rendah memiliki frekuensi siswa terbanyak dari semua kategori prestasi belajar yang ada untuk setiap kategori kompetensi pedagogik guru baik tinggi, cukup dan rendah. 
Berdasarkan hasil perhitungan analisis statistik inferensial menggunakan uji $\mathrm{F}$ diperoleh kesimpulan bahwa kompetensi pedagogik guru sangat berpengaruh dalam meningkatkan motivasi belajar siswa artinya semakin tinggi kompetensi pedagogik guru maka semakin tinggi juga motivasi belajar siswanya buktinya dapat dilihat pada tabel 5 . Hal ini sejalan dengan penelitian Ria Anggita Potabuga, yaitu kompetensi pedagogik berpengaruh signifikan terhadap motivasi belajar siswa pada mata pelajaran produktif 1 studi kasus di kelas X Ak SMK Negeri 1 kota Gorontalo (Potabuga, 2013).

Selanjutnya, berdasarkan hasil perhitungan menggunakan uji Kruskal Wallis diperoleh disimpulkan bahwa tidak terdapat pengaruh kompetensi pedagogik guru terhadap prestasi belajar matematika siswa SMP Negeri di kota Mataram tahun ajaran 2019/2020. Tetapi hasil ini tidak sejalan dengan penelitian Afriyani dkk,yaitu kompetensi pedagogik berpengaruh signifikan terhadap prestasi belajar siswa Madrasah Aliyah An Nur Cirebon pada mata pelajaran aqidah akhlak.Tidak berpengaruhnya kompetensi pedagogik guru terhadap prestasi belajar matematika siswa disebabkan oleh banyak faktor (Afriyani dkk., 2017).

Kembali kepada faktor-faktor yang mempengaruhi prestasi belajar siswa. Peneliti melihat dari segi lain faktor yang mempengaruhi prestasi belajar siswa seperti kemampuan awal siswa. Berdasarkan nilai kemampuan belajar matematika siswa terlihat bahwa mayoritas siswa memiliki kemampuan belajar matematika rendah, begitu juga siswa yang diajarkan oleh guru yang berkategori kompetensi pedagogik tinggi memang siswanya memiliki kemampuan belajar matematika yang rendah. Hal ini sejalan dengan penelitian Astuti, yaitu pengaruh kemampuan awal terhadap prestasi belajar adalah signifikan. Hal tersebut semakin baik kemampuan awal siswa maka akan semakin baik pula juga prestasi belajarnya (Astuti, 2015).

Selain dari tingkat kemampuan awal belajar matematika siswa, dilihat juga dari tingkat kesukaran soal yang digunakan. Menurut pendapat beberapa guru ketika wawancara diperoleh informasi bahwa guru berkategori kompetensi pedagogik tinggi dan rendah mengajar dikelas VIII dengan dengan kriteria soal sulit sehingga diperoleh prestasi belajar matematika siswanya rendah. Sedangkan guru berkategori kompetensi sedang mengajar dikelas VII dengan kriteria soal mudah sehingga diperoleh prestasi belajar matematika siswanya tinggi. Oleh karena itu, wajar saja bahwa prestasi belajar matematika siswa yang diajarkan oleh guru berkategori kompetensi pedagogik sedang lebih tinggi dari prestasi belajar matematika siswa yang diajarkan oleh guru berkategori kompetensi pedagogik tinggi.

Adapun dilihat dari segi perolehan nilai UKG khususnya nilai kompetensi pedagogik guru pada tahun 2015. Nilai UKG tersebut terbilang sudah lumayan lama sehingga dalam selang waktu 5 tahun tersebut tidak menutup kemungkinan guru berkategori kompetensi pedagogik rendah dan sedang terus berproses menjadi lebih baik dalam meningkatkan kualitas mengajarnya. Berikut beberapa cara dilakukan antara lain giat mengikuti segala program pengembangan kualitas mengajar guru dan gencar 
mempelajari dan mendalami serta mengaplikasikan ilmu pengetahuan yang dimilikinya dalam kegiatan belajar mengajar.

Tidak berpengaruhnya kompetensi pedagogik guru terhadap prestasi belajar matematika siswa didukung juga dengan pernyataan beberapa guru yang menyatakan bahwa guru matematika jarang mengajar dikelas tersebut. Hal ini disebabkan guru tersebut sibuk kegiatan diluar sekolah, seperti ikut penataran, mengisi acara keagamaan, dan mengikuti rapat kedinasan. Sehingga mengakibatkan siswa tidak memperoleh ilmu pengetahuan secara utuh yang membuat siswa tidak fokus dan berkonsentrasi pada mata pelajaran matematika yang berpengaruh pada output proses pembelajaran yang diterimanya.

Sementara itu berdasarkan hasil perhitungan menggunakan uji Kendal Tau diperoleh kesimpulan tidak terdapat hubungan antara motivasi dan prestasi belajar matematika siswa SMPN di kota Mataram tahun ajaran 2019/2020. Berdasarkan hasil penelitian pada Tabel 4 terlihat bahwa siswa berkategori motivasi belajar matematika sangat tinggi dan tinggi memiliki frekuensi terbanyak pada kategori kompetensi pedagogik tinggi tetapi dengan siswa berkategori prestasi belajar matematika sangat tinggi dan tinggi memiliki frekuensi paling sedikit dibandingkan dengan kategori kompetensi pedagogik cukup dan rendah. Sedangkan berdasarkan hasil analisis inferensial diperoleh bahwa kompetensi pedagogik berpengaruh terhadap motivasi tetapi tidak berpengaruh terhadap prestasi belajar matematika siswa SMPN kota Mataram tahun ajaran 2019/2020. Sehingga tidak terdapat hubungan antara motivasi terhadap prestasi belajar matematiks siswa SMPN kota Mataram ttahun ajaran 2019/2020.

\section{PENUTUP}

Berdasarkan hasil penelitian dan pembahasan yang telah diuraikan pada bab sebelumnya, maka dapat disimpulkan bahwa: 1) terdapat pengaruh kompetensi pedagogik guru terhadap motivasi belajar matematika siswa SMPN di kota Mataram tahun ajaran 2019/2020, 2) tidak terdapat pengaruh kompetensi pedagogik guru terhadap prestasi belajar matematika SMPN di kota Mataram tahun ajaran 2019/2020, dan 3) tidak terdapat hubungan antara motivasi dan prestasi belajar matematika siswa SMPN di kota Mataram tahun ajaran 2019/2020.

\section{REFERENSI}

Afriyani, E., Suklani, S., \& Ridwan, W. A. (2017). Pengaruh kompetensi pedagogik guru terhadap prestasi belajar siswa Madrasah Aliyah (MA) An-Nur Kota Cirebon (studi pada pembelajaran aqidah akhlak). Al-Tarbawi Al-Haditsah: Jurnal Pendidikan Islam, 2(1), 80-93. https://doi.org/10.24235/tarbawi.v2i1.2029

Astuti, S. P. (2015). Pengaruh kemampuan awal dan minat belajar. Jurnal Formatif, 5(1), 68-75. http://journal.lppmunindra.ac.id/index.php/Formatif/article/view File/ 167/160

Emda, A. (2017). Kedudukan motivasi belajar siswa dalam pembelajaran. Lantanida Journal, 5(2), 93-196. https://doi.org/10.22373/lj.v5i2.2838

Potabuga, R.A. (2013). Pengaruh kompetensi pedagogik guru terhadap motivasi belajar siswa pada mata pelajaran produktif 1 studi kasus di kelas X Ak SMK Negeri 1 Kota Gorontalo. Skripsi. Universitas Negeri Gorontalo.

Slameto. (2010). Belajar dan faktor-faktor yang mempengaruhinya. Jakarta: Rineka Cipta.

Wahyudi, I., \& Kurniati, U. A. (2012). Panduan lengkap uji sertifikasi guru. Jakarta: PT Prestasi 
Pustakaraya.

Zuhairini, Slamet, \& Ghofir, A. (1993). Metodik khusus pendidikan agama. Surabaya: Usaha Nasional.

ZWR. (2019). Kualitas pendidikan, NTB ranking 33 dari 34 provinsi. Mataram: Radar Lombok. 